Gadjah Mada International Journal of Business

\title{
Factors Affecting Poor Strategy Implementation
}

\author{
Muh. DarminAhmad Pella, Ujang Sumarwan, Arief Daryanto, and Kirbrandoko \\ Graduate Program of Management and Business, Bogor AgriculturalUniversity, Indonesia
}

\begin{abstract}
Research on strategy implementation has been developed for three decades, yet only a few studies focus on factors affecting poor strategy implementation. This research evaluates the influence of strategy implementation problems on strategy implementation success and firm performance. This survey was conducted in 60 Indonesian companies and the data were statistically analysed using Structural Equation Modeling Partial Least Square (SEM PLS). The results show significant influence of strategy implementation problems on the degree of successful strategy implementation and perceived firm performance. The seven major obstacles that have impact on poor strategy implementation are: problems related to corporate scorecard, key performance indicators, information technology, competence, performance appraisal, strategy management office, and financial support.
\end{abstract}

Abstrak: Penelitian mengenai implementasi strategi telah berlangsung selama tiga dekade, namun demikian masih sedikit penelitian yang berfokus pada faktor-faktor yang mempengaruhi kegagalan implementasi strategi. Penelitian mengevaluasi pengaruh problem implementasi strategi pada kesuksesan implementasi strategi dan kinerja perusahaan. Survei dilakukan pada 60 perusahaan Indonesia, dan data dianalisis secara statistik dengan Structural Equation Modeling Partial Least Square (SEM PLS). Hasil menunjukkan pengaruh signifikan problem implementasi strategi terhadap tingkat kesuksesan implementasi strategi dan persepsi kinerja perusahaan. Tujuh faktor utama penghambat implementasi strategi yang ditemukan penelitian ini meliputi problem terkaitindikator kinerja perusahaan, indikator kinerja kunci berdasarkan posisi, teknologi informasi, kompetensi karyawan, penilaian kinerja, kantor manajemen strategi serta dukungan keuangan.

Keywords: corporate performance management; firm performance; strategy execution; strategy implementation problem; strategic management

* Corresponding authors. E-mail: m_darmin@yahoo.com.sg, or dap@aidaconsultant.com 


\section{Introduction}

In the literature on management, the concept of strategy was seriously addressed in the second half of the twentieth century. Initially, a heavy volume of studies and research in the strategic management field was focused on strategy formulation. In recent years, however, an evident shift of focus from strategy formulation to strategy implementation has happened (Kalali et al. 2011). While the overwhelming emphasis on strategic planning is being questioned, more researchers and practicioners realize that strategy implementation is more important than strategy formulation. Low and Siesfield (1998) found that, from ten non-financial factors which are considered by financial analysts in corporate valuation, the execution of corporate strategy factor is at the top of the list of the most important factors. The study by Kaplan and Norton (2001) on 275 portfolio managers indicated that a company's ability to implement strategy is far more important than the strategy itself, therefore it is very important in the formation of a corporate management system.

As a process, strategic management consists of formulation, implementation and assessment steps. Organizations face problems in each step. A good strategic decision alone cannot generate value for an organization and its stakeholders if it is poorly implemented. Ramaseshan's (1998) findings showed that companies found conducting strategy formulation (hard implementation activities) easier than carrying out strategy implementation (soft implementation activities). A number of failures in business target achievement can be attributed to strategy implementation failure, not the strategy formulation itself (Beer et al. 1990). This practical gap creates a need to understand more deeply the factors affect- ing unsuccessful strategy implementation, in order to help organizations overcome and prevent failure in implementing strategic initiatives.

\section{Literature Review and Hypothesis Development}

A company's ability to implement its strategy successfully is a result of its ability to overcome obstacles leading to poor strategy implementation. Studies on problems of implementing strategies provide valuable contributions to strategic management. Both scholars and practitioners realize that the problem is very complex, involving many aspects of business management. Some research has identified factors affecting poor strategy implementation using different aspects and approaches (Alexander 1985; AlGhamdi 1998; Shah 2005; Kalali et al. 2011). Research by Alexander (1985) identified twenty-two obstacles to strategy implementation. Al-Ghamdi (1998) evaluated 20 implementation problems in Saudi Arabian companies. Shah's (2005) research contained 21 problems assumed to be the obstacles to successful strategy implementation in India. Kalali et al. (2011) studied 16 problems related to the failure of implementation of strategic decisions in Iran's health service sector. The theoritical gap occurs because the previous studies have only listed problems and not structured and built within the specific framework of the strategic management process.

The purpose of this study is to identify the strategy implementation problems recurring in the strategic management process in Indonesian companies. In order to frame factors affecting poor strategy implementation within a strategic management concept, this study divides the problems into two catego- 
ries. First, seven problems which are related to steps in strategy implementation. Second, nine problems which are related to organizational supporting factors to implement strategy.

Alexander's (1991) research aimed to assess the understanding of the strategies with 782 subjects who were employees from various companies. The findings showed that only 8.7 percent of participants properly understood their company's strategy. Among various levels of employees, it is found that daily employees understand the company strategy less. Shah (2005) stated that lack of understanding about corporate strategy might lead to low employee commitment. Ramaseshan (1998) found that the most important activity in implementation of the strategy is institutionalization of strategies and supporting frontline staff. Hence, the first problem of strategy implementation that this study presents is the inability to create a clear direction in mission, vision and strategy statement and socialize it to all employee (Bourgeois and Brodwin 1984; Mintzberg et al. 1998; Aaltonen and Ikavalko 2002; Simons 2000).

After creating its mission statement, a company's board of directors needs to set up a clear corporate scorecard. Kaplan and Norton (2001) noted this as the operationalization of a company mission statement. Problems occured when this company scorecard and business targets are not communicated to, understood and internalized by, every employee (Rampersad 2003; Kaplan and Norton 2008). Logically, this second problem that might hinder successful strategy implementation is related to the corporate scorecard. Rampersad (2003) argued that after deciding on a corporate scorecard, the next activities in implementing strategies are creating the organizational unit scorecard and the personal scorecard. The personal scorecard serves as a management process to ascertain that the strategy is everyone's responsibility. By the logic of subsequent strategic management process, the third problem affecting poor strategy implementation relates to the lack of clear key performance indicators for each person or positions to support achievement of corporate strategy (Simons 2000; Kaplan and Norton 2001; Teng 2002).

There are also companies using key performance indicators that do not get excellent results and this is caused by low performance targets that create the level of 'business as usual'. By contrast, leading and successful companies consistently set high, stretching, and challenging targets. Jusoh and Parnell (2008) found that reluctance from employees and leaders to accept high targets hampers strategy implementation. Thus low performance target setting, as well as the unwillingness of employees or leaders in accepting stretching targets for performance, present another strategy implementation problem, as it leads to poor strategy implementation.

Setting stretching targets serves as a prequisite to making a good improvement action plan. Action plans serve by providing details of how to achieve a big audacious goal stated in the corporate business objective. Kazmi (2008) mentioned the steps of resource allocation, project implementation and procedural implementation in activating strategies. Hacker et al. (2001) noted that unclear definition of the key activities of the program may occur when implementing the strategy. Shah (2005) found that ill-defined key implementation, tasks and activities as one of main problems of strategy implementation. Poor strategy implementation may happen if company is not clear about programs 
and action plans should be made to implement the company's strategy (Noble 1999; Okumus 2003; Bower and Gilbert 2007).

Strategy implementation involves translating strategic goals into annual performance objectives, together with aligning and motivating employees. Implementation of activities by individuals or organizational units needs performance appraisal and a rewardincentive scheme. A study by Skivington and Daft (1991) showed that performance appraisal is used by top management as one of the tools to implement and evaluate strategy. Rampersad (2003) noted that personal scorecards became effective when individual performances were tied to individual rewards. Neilson et al. (2008) stated that compensation differentiation between high and low performers serve as an element of strong strategy execution. The problems related to performance appraisal and compensation contribute to poor strategy implementation.

Last but not least, and possibly the most important step in strategy implementation, is building a control and monitoring system. Shah's (2005) research found strategy implementation problems caused by insufficient coordination across departmental boundaries and ineffective monitoring. In his framework, Kazmi (2008) argued that a company need to do step evaluation and control after functional and operational implementation, to make sure the company was achieving effectiveness in strategy implementation. Simons (2000) insisted that there was value from four levers of framework control (diagnostic control system, interactive control system, belief system, boundary system) to increase company management control. Peljhan's (2006) study showed that management control systems played an important role in strategy implementation. If no routine and inte- grative system exists in the company to control, monitor and review the implementation and achievement of business targets, then the strategy implementation becomes ineffective (Kaplan 2001).

The strategy implementation stages may be carried out well, but if an organization does not place its capabilities into implementing strategy, then the strategy becomes ineffective. This study identifies nine capabilities needed to enhance the quality of strategy impelementation in every step. The first capability to support strategy execution is inevitably related to company financial support. Companies with good strategy, but with negative cashflow, will not be able to support all strategy implementation activities (Miller 1997; Lingle and Schiemann 1994). This study includes financial problems as a factor leading to poor strategy implementation. If financial and other resources are inadequate to support the implementation then the strategy implementation will become ineffective.

The second important capability for execution relates to leadership. Bossidy (2002) stated that strategy execution is not just tactics -it is a discipline and a system that have to be built into a company's strategy, goals, and culture. The leader of the organization must be deeply engaged in it for it is not top leaders' formal strategies that determine how business gets done, but all the managers and leaders who make decisions in a daily manner. Bower and Gilbert (2007) pointed out that managers' everyday decisions can create or destroy a company's strategy. Al-Ghamdi (1998), Noble (1999), also Nohria et al. (2003) found that leadership is the main factor of successful strategy implementation. Tan (2004) also found that leadership and power are two major obstacles that 
can impede or enhance the success of the organization. Shah's (2005) research found inadequacy in management skills and leadership and direction provided by departmental managers, along with poor comprehension of roles, may affect the quality of strategy implementation. Scant leadership role in guarding, controling and monitoring can downgrade the quality of company strategy implementation.

The third capability to support strategy implementation is improvement process capability. Hacker et al. (2001) argued that continuous improvement is fundamental to strategic implementation success. Consistently delivering high quality results is related to the manager's ability to manage a project, program or action plan. Lack of ability in terms of process improvement and innovation diminished the organization's capability to implementstrategy.

The next capability that plays an important role in strategy execution is information technology. Shah (2005) noted that a poor information system is one of the main obstacles to successful strategy implementation. IT sophistication plays such an important role. In his framework, Kazmi (1998) stated that information technology increases capability in activating, managing, and achieving strategy effectiveness. Lack of support from information technology systems inhibits an organization's capability to implement strategy successfully.

Three important capabilities required to support strategy implementation are related to organizational structure, culture and competence. Okumus' (2001) framework argued that organizational structure plays a role as a connecting factor between external environment context and internal organizational pro- cess in ensuring company achievement of strategic outcomes. Shah (2005) found that indistinct structure and unclear lines of responsibility are parts of the main obstacles in strategy implementation. Roth et al. (1991) found six organizational design needs to be adressed: coordination, managerial philosophy, configuration, formalization, centralization and integration mechanism. Unclear organizational structure makes employees confused and frustated, and impedes successful strategy implementation.

Organizational culture is another important organizational capability able to drive strategy execution. Saunders et al. (2008) inferred that implementing new strategy requires making changes in taken-for-granted assumptions and routines that are elements of culture. Organizational culture underpins success in implementation. An initiative that matches the culture of an organisation can ensure a rapid and successful implementation. A study by Aaltonen and Ikavalko (2002) highlighted the importance of organisational structure and culture receptive to change in order to increase effective strategy implementation. Tan (2004) also noted the importance of positive culture commitment and loyalty of employees to support the strategy implementation. Unclear or negative corporate culture may lead to poor strategy implementation.

Competence is a capability that frequently appears in strategy implementation problem studies (Alexander 1985; Shah 2005; Al-Ghamdi 2008; Kalali et al. 2008). Lack of education, training and development to enhance the competence of employees may obstruct the implementationof strategy. Shah (2005) found that lack of training and instruction on strategy implementation given 
to all employees resulted in insufficient capabilities of employees that leads to poor strategy implementation.

Another important capability to support strategy implementation is change management. New strategy necessitates change, whether it is structural, cultural, operational, or another. It is accepted that change management is one of the capabilities to support successful strategy implementation. Kazmi (2008) pointed out that successful strategic implementation implied change for the organization. A lack of program improvement or change management may lead to poor strategy implementation. Change management problems lead to poor strategy implementation.

A new construct of capabilities to support strategy execution, which has not been used in previous studies, is strategy management office. As Kaplan and Norton (2008) stated, a company may have difficulties in executing strategy because no organization unit is specifically assigned by top management to oversee/monitor the implementation of the company strategy. Therefore, this study includes strategy management office as one of capabilities affecting strategy implementation.

In summary, this research evaluated 16 strategy implementation problems. Seven problems concerned the strategy implementation steps, which are related to mission statement, corporate scorecard, key performance indicators, action plan, performance appraisal and compensation, also control and monitoring system. Nine problems concerned capabilities to support strategy implementation which are related to financial capability, leadership, continuous improvement, information technology, culture, organizational structure, HR competence, change management, and strategy management office.

In this research, a list of problems is defined to provide a comprehensive approach to strategic management. The novelty of this research lies in the structurization and categorization of strategy implementation problems. Whereas previous studies have listed problems relevant to strategy implementation, this study presents a framework containing problems in the strategic management proces that are differentiated into two main categories. The first category includes seven problems which occur in the strategy implementation steps.

The second category consists of nine problems related to an organization's capabilities to execute the strategy. Each category and problem is explained to ensure no redundancy in defining problems. Other contributions of this study are also presented in the form of strategy implementation problems which are expected to be available cross-industry. Previous research put some factors which were not applicable in different industries, such as problems related to size, geographic location of the company, company life cycle, or manager demographic background (Schmelzer and Olsen 1994). From this point of view, it is hoped that the study can be replicated in all type of business, industry and countries. This study differs from other previous studies essentially because the problems chosen have been excluded from aspects which are actually the output of the main problems. For example, previous a study mentions "took more time than originally allocated" (AlGhamdi 1998) as a problem, whereas it is the effect as a cause of lack of competence or weakness in controling and monitoring strategy implementation activities. Considering the previous studies had been conducted in 
America, Europe, and Middle East, this study provides understanding of obstacles to effective strategy implementation in Asia, especially in Indonesian companies.

\section{Hypothesis}

A company's inability to overcome problems related to its mission statement (Okumus 2003), corporate scorecard (Kaplan and Norton 2008), key performance indicators (Rampersad 2003), stretching targets (Jusoh and Parnell 2008), improvement action plan (Kazmi 2008), performance appraisal and compensation (Neilson et al. 2008), also control and monitoring system (Simons 2000) may lead to unsuccessful strategy implementation. Also, when a company does not provide or develop capabilities to support strategy implementation such as financial capability (Lingle and Schieman 1994), leadership (Nohria et al. 2003), continuous improvement (Hacker et al. 2001), information technology (Al-Ghamdi 1998), organizational structure (Kazmi 2008), cul- ture (Saunders et al. 2008), HR competence (Lingle and Schiemann 1994), change management (Kazmi 2008), and strategy management office (Kaplan and Norton 2008), then it will affect the quality of strategy implementation (see Figure 1). This leads to $\mathrm{H}_{1}$ (Hypothesis 1)

$H_{1}$ : The strategy implementation problems are negatively associated with the degree of success in strategy implementation.

Successful strategy implementation means every person in the company works together and contributes to the effort of strategy implementation (Harrington and Kendall 2006). It also means that strategy implementation activities help the company to gain more efficiencies, increase revenues or achieve strategic targets (Olson and Slater 2002). A successful strategy implementation leads to better firm performance (Nohria et al. 2003; Jusoh and Parnell 2008). This leads to $\mathrm{H}_{2}$ (Hypothesis 2).

$H_{2}$ : The degree of success in strategy implementation is positively associated with the perceived firm performance.

Figure 1. Research Model

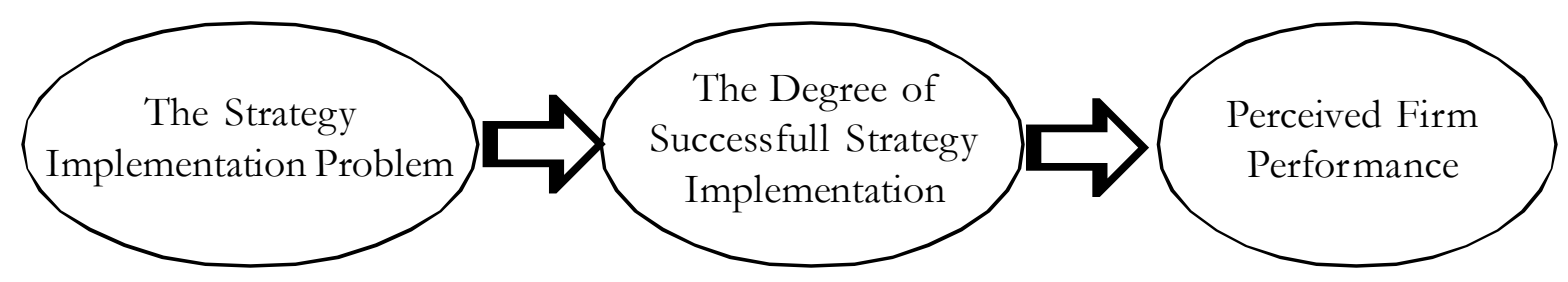




\section{Data and Methods}

This research focuses on factors affecting the quality of strategy implementation and the impact on strategy implementation success and firm performance. A survey is used in this study to collect data, using a questionnaire which contains of sections for respondent data, strategic choice implemented in a company, strategy implementation problems, degree of successful implementation of the strategy, perceived firm performance, and open questions on strengths and weaknesses of strategy implementation practices. The data were processed using SEM techniques Partial Least Square (PLS) with SmartPLS 2.0 software.

In line with the study of Al-Ghamdi (1998), in completing the questionnaire, the respondents were first asked to identify strategic options that had been set by the company. Respondents could identify one or more strategic options known to them that were implemented by their company. There are seven strategic options related to the development of business units; research, development, launch of new product or services; development of facilities, branches, or new plants; partnership, alliance, merger, or acquisition by another company; increase in sales and marketing programs, management systems or new software implementation, and company's operational efficiency. Blanks were provided for respondents to explain company strategies that were not listed in the questionnaire.

\section{Research Variable}

Subsequent to the examination and check on redundancy of problems through literature research studies, a list of 16 factors leading to poor strategy implementation is proposed as the strategy implementation problem variables (see Table 1).

Using the Likert scale to measure the variables, respondentswere asked to provide evaluation of 1 (strongly not agree), 2 (not agree), 3 (no opinion), 4 (agree), 5 (strongly agree) for any problem with strategy implementation. Respondents were also asked to rate the degree of success of current strategy implementation with indicators about whether the implementation support business achievement, the extent of stakeholders contribution and how much the strategy implementation helps the company to increase corporate revenue, lowering costs or decreasing inefficiencies. The successful implementation of the strategy was assessed using a 5 point scale ranging from 1-strongly not agree to 5strongly agree (Al-Ghamdi 1998; Harrington and Kendall 2006).

Table 1. Problems of Poor Strategy Implementation

\begin{tabular}{|c|c|c|}
\hline Dimension & Definition & Previous Study Related \\
\hline $\begin{array}{l}1 \text { - Mission } \\
\text { Statement }\end{array}$ & Direction of the mission, vision, and strategy is not clear & $\begin{array}{l}\text { Bourgeois and Brodwin 1984; } \\
\text { Mintzberg et al. 1998; } \\
\text { Aaltonen and Ikavalko 2002; } \\
\text { Simons 2000; Okumus } 2003\end{array}$ \\
\hline $\begin{array}{r}2 \text { - Corporate } \\
\text { Scorecard }\end{array}$ & $\begin{array}{l}\text { The company's scorecard and business target is not } \\
\text { communicated to, understood and internalized by every } \\
\text { employee }\end{array}$ & $\begin{array}{l}\text { Rampersad 2003; Kaplan and } \\
\text { Norton 2001, and 2008) } \\
\text { Kaplan and Norton 2008) }\end{array}$ \\
\hline
\end{tabular}




\section{Table 1 (Continued)}

\begin{tabular}{|c|c|c|}
\hline Dimension & Definition & Previous Study Related \\
\hline $\begin{array}{l}3 \text { - Key } \\
\text { Performance } \\
\text { Indicator }\end{array}$ & $\begin{array}{l}\text { There is no clear indication of the the key performance } \\
\text { indicators for each person/positions to support the } \\
\text { achievement of corporate strategy }\end{array}$ & $\begin{array}{l}\text { Simons 2000; Kaplan and } \\
\text { Norton 2001; Teng 2002; } \\
\text { Bossidy 2002; Rampersad } 2003\end{array}$ \\
\hline 4-Stretching Target & $\begin{array}{l}\text { Performance targeting low, employees/leaders are less } \\
\text { willing to accept the high/stretching target for performance }\end{array}$ & Jusoh and Parnell 2008 \\
\hline 5 - Action Plan & $\begin{array}{l}\text { It is not clear programs and action plans should be made } \\
\text { to implement the company's strategy }\end{array}$ & $\begin{array}{l}\text { Noble 1999; Hacker et al. 2001; } \\
\text { Okumus 2003; Bower and } \\
\text { Gilbert 2007; Kazmi } 2008\end{array}$ \\
\hline $\begin{array}{l}\text { 6- Performance } \\
\text { Appraisal }\end{array}$ & $\begin{array}{l}\text { There is no performance appraisal based on KPI and } \\
\text { individual performance was not tied with compensation }\end{array}$ & $\begin{array}{l}\text { Skivington and Daft 1991; } \\
\text { Rampersad 2003; Neilson et al. } \\
2008\end{array}$ \\
\hline $\begin{array}{l}7 \text { - Control and } \\
\text { Monitor }\end{array}$ & $\begin{array}{l}\text { No routine and integrative system to control, monitor and } \\
\text { review the implementation and achievement of business } \\
\text { targets }\end{array}$ & $\begin{array}{l}\text { Simons 2000;Kaplan 2001; } \\
\text { Peljhan 2006; Kazmi } 2008\end{array}$ \\
\hline 8 - Financial & $\begin{array}{l}\text { Financial and other resources are inadequate to support } \\
\text { the implementation of the strategy }\end{array}$ & $\begin{array}{l}\text { Miller 1997; Lingle and } \\
\text { Schiemann } 1994\end{array}$ \\
\hline 9 - Leadership & $\begin{array}{l}\text { Inadequate leadership rolein guarding, controling and } \\
\text { monitoring the implementation of the company strategy }\end{array}$ & $\begin{array}{l}\text { Al-Ghamdi 1998; Noble 1999; } \\
\text { Nohria et al. } 2003\end{array}$ \\
\hline 10 - Improvement & $\begin{array}{l}\text { Employees and management lack the ability for process } \\
\text { improvement and innovation to support the } \\
\text { implementation of company strategy }\end{array}$ & Hacker et al. 2001 \\
\hline $\begin{array}{l}11 \text { - Information } \\
\text { Technology }\end{array}$ & $\begin{array}{l}\text { Less support from information technology systems, } \\
\text { processing and transaction processing work is done } \\
\text { manually }\end{array}$ & Al-Ghamdi 1998 \\
\hline 12 - Structure & $\begin{array}{l}\text { Lack of organizational structure that reflects the clear } \\
\text { division of work and responsibilities }\end{array}$ & $\begin{array}{l}\text { Roth et al. 1991; Okumus 2003; } \\
\text { Kazmi } 2008\end{array}$ \\
\hline 13 - Culture & $\begin{array}{l}\text { A corporate culture that is less clear, is still weak, tends to } \\
\text { be negative }\end{array}$ & $\begin{array}{l}\text { Peters 1980; Dickenson 2009; } \\
\text { Saunderset al. } 2008\end{array}$ \\
\hline 14 -Competence & $\begin{array}{l}\text { Lack of education, training and development to enhance } \\
\text { the competence of employees implementing the strategy }\end{array}$ & $\begin{array}{l}\text { Lingle and Schiemann 1994; } \\
\text { Okumus } 2001\end{array}$ \\
\hline $\begin{array}{l}\text { 15- Change } \\
\text { Management }\end{array}$ & $\begin{array}{l}\text { There is no program improvement/change management } \\
\text { program management launched }\end{array}$ & Kazmi 2008 \\
\hline $\begin{array}{l}\text { 16- Strategy } \\
\text { Management } \\
\text { Office }\end{array}$ & $\begin{array}{l}\text { No person/organization unit (section/dept/division) } \\
\text { specifically assigned by top management to oversee/ } \\
\text { monitor the implementation of the company strategy }\end{array}$ & Kaplan and Norton 2008 \\
\hline
\end{tabular}


The variable of perceived firm performance is adapted from Tessema and Sooter (2006), using assessment on company ability to reach target revenue/profit, performance growth in the last three years, company ability to achieve performance targets (operational/marketing/finance), and comparison of company performance with the performance of other similar companies in the same industry in Indonesia. The perceived firm performance was assessed using a 5 point scale ranging from 1 -strongly not agree to 5 strongly agree.

\section{Partial least square anaysis}

Steps of data analysis and structural equation modeling using PLS are as follow:

a. Designing Structural Model (Inner Model)

b. Designing Model Measurement (Outer Model)

c. Conversion Chart Path to Systems of Equations. Basic equation model of Inner Model can be written as follows:

$$
\begin{aligned}
& \eta_{\mathrm{i}}=\beta \eta_{\mathrm{i}}+\Gamma \xi_{\mathrm{i}}+\zeta_{\mathrm{i}^{*}} \\
& \mathrm{y}_{\mathrm{i}}=\Lambda_{\mathrm{y}} \eta_{\mathrm{i}}+\varepsilon_{\mathrm{i}} \\
& \mathrm{X}_{\mathrm{i}}=\Lambda_{\mathrm{x}} \xi_{\mathrm{i}}+\delta_{\mathrm{i}}
\end{aligned}
$$

where

$\eta_{i}=$ Latent endogenous variables (for observation i)

$\xi_{\mathrm{i}}=$ Latent enxogenous variables

$\zeta_{\mathrm{i}}=$ Structural disturbances (errors in equations)

$\beta=$ Structural parameters relating latent endogenous variables
$\Gamma=$ Structural parameters relating latent endogenous to exogenous variables

$\mathrm{y}_{\mathrm{i}}=$ Indicators of latent endogenous variables

$\mathrm{X}_{\mathrm{i}}=$ Indicators of latent exogenous variables

$\varepsilon_{\mathrm{i}}=$ Measurement errors in endogenous indicators

$\delta_{\mathrm{i}}=$ Measurement errors in exogenous indicators

$\Lambda_{\mathrm{x}} \Lambda_{\mathrm{y}}=$ Factors loadings relating indicators to latent variables

d. Weight Estimation, Path coefficient and Loading.

e. Resampling bootstrapping: Hypothesis Testing $(\beta$, y, and $\lambda)$. Statistics test used is t-test.

\section{Sampling technique}

The convenience sampling method is applied in this study, in which samples of companies were selected from the database of a management consultant, comprising companies in Indonesia in a variety of fields, ranging from agribusiness, manufacturing, and trade, to finance, property, services, and others. Invitations to participate were sent by e-mail, then followed by a questionnaire to be filled in if the company consented to join in as a respondent.

The same sampling technique was used by Ramaseshan (1998), Al-Ghamdi (1998), Shah (2005), Pucko and Cater (2008), and Jooste and Fourie (2009). The use of subjects from various industries was based on several considerations. First, with every company having at least one strategy, the number of types of company would present diversity of research input. Second, it was more 
convinient to get enough data from many companies in various industries in Indonesia than from a single type. Third, the availability of company or group of companies in a single industry in Indonesia who were willing to provide full depth information on their strategic management from all level of employee to external researchers was a slim possibility.

Supervisors, managers, general managers and directors were targeted as respondents to obtain varying input according to level of the position and role in strategy implementation. Respondents would display differences in perceptions on every aspect of the implementation strategy from each position's point of view. Strategic management literature is full of thoughts and perceptions of executives, as strategy was made at directorial level. As implementation of strategy particularly involves the levels furthest from the directors (Pella 2010), acquiring ideas and perceptions from managerial levels would enrich the problem analysis and discussion. SEM studies suggested sample size of 5 to 10 times the number of variables or around 100 to 200 respondents. In this study, the data analysed were from 194 respondents with various job level i.e. supervisors, managers, general managers, and directors

\section{Respondents}

Of the 194 respondents from 60 companies of various industries in Indonesia, most respondents were male $(84 \%)$. As for job level, 53 percent of respondents were supervisors, while 34 percent were managers, 10 percent were general managers and 3 percent directors. University graduates made up the majority of respondents (51\%), while the rest were high school or equivalent $(18 \%)$, diploma $(19 \%)$, and post-graduates $(12 \%)$.

\section{Results and Discussion}

\section{Result of Measurement Model Evaluation}

The first step of SEM analysis evaluated the measurement model. The validity and reliability of each construct was evaluated with confirmatory factor analysis (CFA). Output of SmartPLS provided statistical analysis results to check convergent validity and discriminant validity. Individual item reliability check was evaluated through standardized a loading factor (SLF), with ideal value requirement above 0.70 . For new indicators development, SLF $>0.50$ indicated a good validity. Indicators with $\mathrm{SLF}<0.50$ were taken out from the model (Chin 1998 in Yamin and Kurniawan 2011). Evaluation of the statistical value showed all indicators had good validity with value of $t$ statistics above 2.0 (as shown in Table 2).

Further examination of convergent validity used both Cronbach alpha and Average Variance Extracted (AVE). The criteria is reliable when the value of Cronbach alpha is more than 0.70 . A construct also has a good convergent validity when the AVE value is more than 0.50 . Composite reliability (CR) is reached when the value is above 0.70 . Below is the result PLS Quality Criteria (CA, AVE, CR, R Square). The SmartPLS output indicates that every construct shows good reliability, Thus it can be stated that the whole construct has good validity. 
Table 2. Outer Loading Output (Mean, STDEV, $T$-Values)

\begin{tabular}{lccccc}
\hline Path & $\begin{array}{c}\text { Original } \\
\text { Sample } \\
\mathbf{( O )}\end{array}$ & $\begin{array}{c}\text { Sample } \\
\text { Mean (M) }\end{array}$ & $\begin{array}{c}\text { Standard } \\
\text { Deviation } \\
\text { (STDEV) }\end{array}$ & $\begin{array}{c}\text { Standard } \\
\text { Error } \\
\text { (STERR) }\end{array}$ & $\begin{array}{c}\text { T Statistics } \\
(\mid \mathbf{O} / \text { STERR|) }\end{array}$ \\
\hline PE1 <- SIP & 0.779050 & 0.772447 & 0.039650 & 0.039650 & 19.648 .097 \\
PE2 <- SIP & 0.808116 & 0.810435 & 0.033364 & 0.033364 & 24.221 .501 \\
PE3 <- SIP & 0.802783 & 0.801162 & 0.031588 & 0.031588 & 25.414 .083 \\
PE4 <- SIP & 0.771894 & 0.768189 & 0.034726 & 0.034726 & 22.228 .061 \\
PE5 <- SIP & 0.861612 & 0.860855 & 0.023444 & 0.023444 & 36.752 .358 \\
PE6 <- SIP & 0.776729 & 0.773154 & 0.031267 & 0.031267 & 24.842 .188 \\
PE7 <- SIP & 0.790640 & 0.786970 & 0.035824 & 0.035824 & 22.070 .111 \\
PE8 <- SIP & 0.737054 & 0.727653 & 0.043560 & 0.043560 & 16.920 .414 \\
PE9 <- SIP & 0.849340 & 0.845968 & 0.026226 & 0.026226 & 32.385 .088 \\
PE10 <- SIP & 0.852338 & 0.852476 & 0.024564 & 0.024564 & 34.698 .699 \\
PE11 <- SIP & 0.694699 & 0.686478 & 0.050656 & 0.050656 & 13.714 .036 \\
PE12 <- SIP & 0.781892 & 0.771523 & 0.037121 & 0.037121 & 21.063 .186 \\
PE13 <- SIP & 0.805908 & 0.804496 & 0.027866 & 0.027866 & 28.920 .449 \\
PE14 <- SIP & 0.739572 & 0.733067 & 0.039777 & 0.039777 & 18.593 .151 \\
PE15 <- SIP & 0.816468 & 0.812489 & 0.028850 & 0.028850 & 28.300 .195 \\
PE16 <- SIP & 0.776487 & 0.771236 & 0.044235 & 0.044235 & 17.553 .802 \\
DSSI1 <- DSSI & 0.818927 & 0.819960 & 0.018773 & 0.018773 & 43.623 .324 \\
DSSI 2 <- DSSI & 0.829175 & 0.827213 & 0.027722 & 0.027722 & 29.910 .641 \\
DSSI 3 - DSSI & 0.852215 & 0.853871 & 0.019172 & 0.019172 & 44.451 .388 \\
DSSI 4 <- DSSI & 0.819072 & 0.815117 & 0.035364 & 0.035364 & 23.161 .242 \\
DSSI 5 <- DSSI & 0.729648 & 0.720504 & 0.056217 & 0.056217 & 12.979 .039 \\
FP1 <- PERF & 0.799528 & 0.797503 & 0.038294 & 0.038294 & 20.878 .782 \\
FP2 <- PERF & 0.822765 & 0.819049 & 0.033496 & 0.033496 & 24.562 .873 \\
FP3 <- PERF & 0.805130 & 0.803056 & 0.037190 & 0.037190 & 21.649 .345 \\
FP4 <- PERF & 0.752999 & 0.752895 & 0.040420 & 0.040420 & 18.629 .192 \\
FP5 <- PERF & 0.777668 & 0.772667 & 0.052148 & 0.052148 & 14.912 .739 \\
FP6 <- PERF & 0.778116 & 0.774719 & 0.032134 & 0.032134 & 24.214 .921 \\
\hline & & & & & \\
\hline
\end{tabular}


Gadjah Mada International Journal of Business - Mag-August, Vol 15, Na 2, 2013

Table 3. Output PLS Quality Criteria (AVE, CR, R Square, CA)

\begin{tabular}{lcccccc}
\hline & AVE & $\begin{array}{c}\text { Composite } \\
\text { Reliability }\end{array}$ & R Square & $\begin{array}{c}\text { Cronbachs } \\
\text { Alpha }\end{array}$ & $\begin{array}{c}\text { Com- } \\
\text { munality }\end{array}$ & $\begin{array}{c}\text { Redun- } \\
\text { dancy }\end{array}$ \\
\hline PERF & 0.623610 & 0.908532 & 0.616752 & 0.879162 & 0.623610 & 0.383065 \\
DSSI & 0.657542 & 0.905435 & 0.121434 & 0.869471 & 0.657542 & 0.079952 \\
SIP & 0.626382 & 0.963959 & & 0.960127 & 0.626382 & \\
\hline
\end{tabular}

Table 4. Output PLS - Cross Loading

\begin{tabular}{cccc}
\hline ITEM & SIP & DSSI & PERF \\
\hline PE1 & 0.779050 & -0.227660 & -0.140698 \\
PE2 & 0.808116 & -0.301109 & -0.285820 \\
PE3 & 0.802783 & -0.299661 & -0.282750 \\
PE4 & 0.771894 & -0.239191 & -0.201855 \\
PE5 & 0.861612 & -0.345927 & -0.260276 \\
PE6 & 0.776729 & -0.263929 & -0.236115 \\
PE7 & 0.790640 & -0.324774 & -0.308691 \\
PE8 & 0.737054 & -0.154694 & -0.192003 \\
PE9 & 0.849340 & -0.304292 & -0.291079 \\
PE10 & 0.852338 & -0.328912 & -0.322545 \\
PE11 & 0.694699 & -0.212190 & -0.215578 \\
PE12 & 0.781892 & -0.174322 & -0.201676 \\
PE13 & 0.805908 & -0.289817 & -0.294086 \\
PE14 & 0.739572 & -0.226511 & -0.221995 \\
PE15 & 0.816468 & -0.292931 & -0.296974 \\
PE16 & 0.776487 & -0.282899 & -0.237572 \\
KI1 & -0.273333 & 0.818927 & 0.706950 \\
KI2 & -0.262809 & 0.829175 & 0.673896 \\
KI3 & -0.325025 & 0.852215 & 0.666045 \\
KI4 & -0.309844 & 0.819072 & 0.594987 \\
KI5 & -0.238334 & 0.729648 & 0.520573 \\
FP1 & -0.234806 & 0.638121 & 0.799528 \\
FP2 & -0.295649 & 0.629518 & 0.822765 \\
FP3 & -0.214171 & 0.632658 & 0.805130 \\
FP4 & -0.206244 & 0.552357 & 0.752999 \\
FP5 & -0.189963 & 0.597056 & 0.777668 \\
FP6 & -0.375233 & 0.661597 & 0.778116 \\
\hline & & & \\
\hline
\end{tabular}


Another important result of SmartPLS is cross loading. Table 4 shows the correlation between indicators and its construct compared to correlation to other constructs. It is considered a good indicator of discriminant validity if the correlation between the indicator to its construct is higher than another construct. According to the table, each indicator correlated higher with corresponding construct than to another construct, thus all items have good discriminant validity value.

\section{Result of Structural Model Evaluation}

SmartPLS predicts causal relationships among latent variables through a boot-strapping process to get $t$-statistic test parameters. PLS structural model evaluates path coefficients or $t$-values for each path between the construct. The following table shows $t$-statistic output and interpretation of hypothesis tests performed in this study.

Hypothesis 1 stipulated that strategy implementation problems (SIP) are negatively associated with the degree of successful strat- egy implementation (DSSI). SmartPLS output shows that SIP is a significant and negative influence on DSSI $\left(\beta_{1}=-0.348, \mathrm{t}=4.159\right.$, $\mathrm{p}<0.01)$. Hypothesis 2 postulated that the degree of success ful strategy implementation (DSSI)influence Perceived Firm Performance (PERF). We find a significant influence of DSSI on PERF $\left(\beta_{2}=0.785, \mathrm{t}=25.548\right.$, $\mathrm{p}<0.01)$. Thus, $\mathrm{H}_{2}$ is also supported.

The next step of structural model evaluation was done by assesing $R$-square. In the PLS method, goodness of fit model is evaluated using interpretation of $\mathrm{R}$-Square. Rsquare interpretation can be explained in equal meaning with regression interpretation. Changes in R-square reflect influence of independent latent variable to dependent latent variable whether substantial, moderate or weak (Ghozali 2008).Chin (1998, in Yamin and Kurniawan 2011) explain criteria for interpreting $\mathrm{R}$-square in three classifications, that is 0.67 (substantial), 0.33 (moderate), and 0.19 (weak). Based on statistical output, construct DSSI explains the variability of construct PERF as much as 61.7 percent. The construct SIP explain variability of construct DSSI as much as 12.1 percent.

Table5. Output Path Coefficients (Mean, Std Dev, $\boldsymbol{t}$-values)

\begin{tabular}{lccccc}
\hline Path & $\begin{array}{c}\text { Original } \\
\text { Sample } \\
(\mathbf{O})\end{array}$ & $\begin{array}{c}\text { Sample } \\
\text { Mean } \\
\mathbf{( M )}\end{array}$ & $\begin{array}{c}\text { Standard } \\
\text { Deviation } \\
\mathbf{( S T D E V )}\end{array}$ & $\begin{array}{c}\text { Standard } \\
\text { Error } \\
(\mathbf{S T E R R})\end{array}$ & $\begin{array}{c}\text { T-Statistics } \\
(\mid \mathbf{O} / \text { STERR })\end{array}$ \\
\hline SIP -> DSSI & -0.348 & -0.355 & 0.083 & 0.083 & 4.159 \\
DSSI ->PERF & 0.785 & 0.782 & 0.030 & 0.030 & 25.548 \\
\hline
\end{tabular}

Note: SIP = Strategy Implementation Problem, DSSI = Degree of Successful Strategy Implementation, PERF = Perceived Firm Performance 


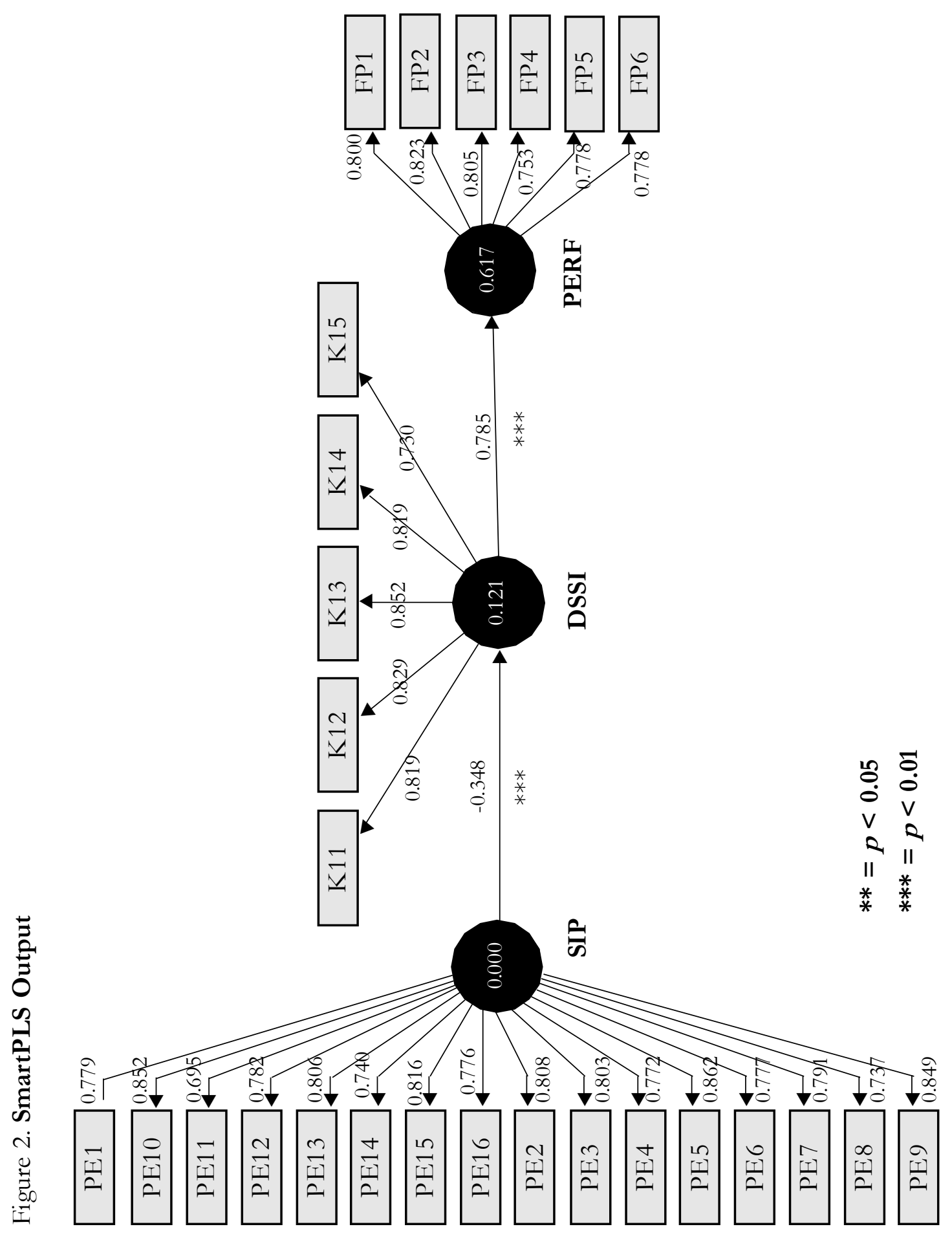




\section{Discussion of Findings}

The objective of the study was to analyze the main factors inhibiting implementation of company strategy. Results highlight the need to manage problems at each step of strategy implementation to prevent and overcome poor strategy implementation. Top management who can manage those problems will provide a company with a high degree of successful strategy implementation, which will lead to increased firm performance.

Evaluation of which problem most significantly affects strategy implementation can be observed in Table 2 and Table 4. PE5 being the most significant aspect (cross loading 0.346) read that the problem of unclear programs and action plans greatly affect poor strategy implementation. The second aspect affecting poor strategy implementation is employees' and management's lack of ability to improve and innovate the process in supporting implementation of company strategy (PE10 with cross loading 0.329). The third most significant problem represented as PE7 that read no routine and integrative system to control, monitor and review the implementation and achievement of business targets (cross loading 0.324).

Assessment of 16 indicators for detailed observation includes examination of which of the seven problems are associated with poor quality of strategy implementation phase, and which of the nine problems are as sociated with the lack of organizational capability to support strategy implementation.There are seven major strategy implementation problems found in this study, namely problems related to Corporate Scorecard, Key Performance Indicators, Information Technology, Competence, Perfor- mance Appraisal, Strategy Management Office, and Financial Support.

The most prominent problem inhibiting strategy implementation is the "target company's business to be achieved/objective is not communicated, understood and internalized by everyone at the company". The performance indicators of the company itself might be less than clear and thus prevent the required understanding. The company may also fail to effectively explain performance indicators so that they are understood by all managers and employees.

The second major problem related to key performance indicators, as as perceived by respondents was: "no clear key performanceindicators for the performance of each person/position to support the achievement of corporate strategy". There are three causes of this problem. First, the indicators of success for departments and individuals were unclear to the appointed functionaries. Second, respondents whose company had adopted KPI in performance appraisal argued about inconsistencies in the KPI implementation. Third, companies that had implemented KPI found that attention to each KPI narrowed employees' focus on managing their job.

The third major problem was related to information technology. Lack of support systems to process transactions or work done manually was a factor that inhibited successful strategy implementation. Information technology problems can be categorized into two aspects. First, the limitations of facilities and modernization of the hardware. Second, the problems related to the development and refinement of software applications and information technology in the enterprise systems (systems and software). 
Gadjah Mada International Journal of Business - Maj-August, Vol 15, Na 2, 2013

Table 6. Findings on Factors Affecting Quality of Strategy Implementation

\begin{tabular}{|c|c|c|c|}
\hline Problem & Definition & $\begin{array}{l}\text { Average } \\
\text { Score }\end{array}$ & $\%$ S\&SS \\
\hline $\begin{array}{l}\text { Corporate } \\
\text { Scorecard }\end{array}$ & $\begin{array}{l}\text { The company's scorecard and business target is } \\
\text { not communicated to, understood and } \\
\text { internalized by, every employee }\end{array}$ & 2.897 & $37.44 \%$ \\
\hline $\begin{array}{l}\text { Key } \\
\text { Performance } \\
\text { Indicator }\end{array}$ & $\begin{array}{l}\text { There is no clear indication of the key } \\
\text { performance indicators for each person/position } \\
\text { to support the achievement of corporate strategy }\end{array}$ & 2.826 & $36.41 \%$ \\
\hline $\begin{array}{l}\text { Information } \\
\text { Technology }\end{array}$ & $\begin{array}{l}\text { Less support from information technology } \\
\text { systems, processing and transaction processing } \\
\text { work is done manually }\end{array}$ & 2.790 & $35.38 \%$ \\
\hline Competence & $\begin{array}{l}\text { Lack of education, training and development to } \\
\text { enhance the competence of employees } \\
\text { implementing the strategy }\end{array}$ & 2.790 & $34.36 \%$ \\
\hline $\begin{array}{l}\text { Performance } \\
\text { Appraisal }\end{array}$ & $\begin{array}{l}\text { There is no performance appraisal based on KPI } \\
\text { and individual performance was not tied to } \\
\text { compensation }\end{array}$ & 2.800 & $32.82 \%$ \\
\hline $\begin{array}{l}\text { Strategy } \\
\text { Management } \\
\text { Office }\end{array}$ & $\begin{array}{l}\text { No person/organization unit (section/dept/ } \\
\text { division) specifically assigned by top } \\
\text { management to oversee/monitor the } \\
\text { implementation of the company strategy }\end{array}$ & 2.821 & $31.79 \%$ \\
\hline $\begin{array}{l}\text { Financial } \\
\text { Capability }\end{array}$ & $\begin{array}{l}\text { Financial and other resources are inadequate to } \\
\text { support the implementation of the strategy }\end{array}$ & 2.774 & $30.26 \%$ \\
\hline
\end{tabular}

Note: $\%$ S\&SS = Setuju dan Sangat Setuju (Agree and Strongly Agree) 
Issues relating to competence as barriers to strategy implementation were raised by respondents. Major problems found in this study related to HR competence. A lack of education, training and development to enhance employee competence in implementing strategy affects the quality of strategy implementation. Competence problems can be categorized into five aspects. First, the number and composition of employees within adequate competence. Second, companies having no system to build and develop competency regularly. Third, a lack of quality human resource development programs concerning competencies. Fourth, competencies of employees not being developed equally across positions within the company. Fifth, HR role not being optimal in supporting the implementation of corporate strategy.

Respondents also argued that one of the factors inhibiting the implementation of the strategy is "no objective performance assessment and achievement of individual performance was not associated with compensation". Problem assessment and performancerelated compensation, according to respondents, can be categorized into four aspects. First, there was no performance-based assessment system. Second, the existing performance appraisal was considered less objective and integrative. Third, the company had not implemented satisfactory performance-based reward systems. Fourth, differentiation of reward between high and low performers was not significant.

The unavailability of a strategy management office was also considerd one of the main factors contributing to strategy implementation problems. Poorstrategy implementation occurs because no person or organizational unit (such as a section, department, or division) is specifically commissioned by top management to oversee and monitor the implementation of strategy. There are three aspects to this problem. First, there was no awareness that, in implementating strategy, a company needs a special unit working full time maintaining ongoing implementation activities. Second, despite the emerging consciousness, there was no unit or organization assigned to monitor or oversee strategy. Third, managerial capability in guarding and monitoring implementation of corporate strategy was inadequate. These findings support the notion of Kaplan and Norton (2005) that one of the major problems of implementation of corporate strategy today is a fragmented management process. Companies generally have different management processes performed by different departments, without an integrated strategy perspective.

The lack of financial support emerged as one of the major problems inhibiting the implementation strategy. Top management was perceived as not providing strong financial support for achievement of corporate strategy. Financial support and other resources are perceived to be inadequate to support the implementation of strategy. This problem is caused by two conditions. First, there is a lack of funds or budget to support strategy. Second, there is a lack of adequate facilities and infrastructure to implement strategies. Respondents noted that lack of supporting funding or budget may prevent the smoothness of the program and activities related to the company's strategy.

\section{Managerial Implication}

Poor strategy implementation might be prevented if top management pays attention to all the organizational supporting factors capabilities needed to execute strategy, especially those related to information technol- 
ogy, competence, strategy management office, and financial support. During the strategy implementation process, top management should carefully manage all problems that occur in the process of the deployment of corporate scorecard, key performance indicators, and performance appraisal. We suggest that top management change or improve the organization structure first to ascertain that each role in strategy management is embedded in the structure, with leadership from director or general manager level. Second, a company needs to make sure that a budget to fund the strategy implementation is in place, and that it is used to increase HR competence and modernize the IT system. Aside from this, management should manage the process of corporate scorecard deployment. Using a bottom-up approach in defining the corporate scorecard and KPI can serve to increase ownership and understanding of the corporate strategy and scorecard. Management should also ensure that performance appraisal reflects the level of individual contributions to company profitability, by differentiating between best, good, average and poor performer with regard to compensation and incentives. This way, the company also builds a high performance culture. Solving all the problems related to strategy implemen- tation steps and capabilities helps a company to avoid poor strategy implementation.

\section{Conclusion}

Research on strategy implementation in Indonesia is necessary to enrich the conceptual framework for strategy implementation that is suitable for Indonesian business culture. This study develops a new strategy implementation problem framework model that contains seven factors of strategy implementation stages and nine factors of supporting capabilities to strategy implementation. Failure to manage these factors leads to an accumulation of problems that degrade the successful implementation of strategy. Among the sixteen factors of strategy implementation problems studied, there are seven major strategy implementation problems found in this study, including problems related to corporate scorecard, key performance indicators, information technology, competence, performance appraisal, strategy management office, and financial support. This study shows significant influence of strategy implementation problems on the degree of successful strategy implementation and perceived firm performance.

\section{References}

Aaltonen, P., and H. Ikavalko. 2002. Implementing strategies successfully. Integrated Manufacturing Systems 13 (6): 415-18.

Alexander, L. 1985. Successfully implementing strategic decision. Long Range Planning 18: 91-97.

Alexander, L. D. 1991. Strategy implementation: nature of the problem. In Hussey D. (Ed.), International Review of Strategic Management 2 :73-96. New York: John Wiley and Sons.

Al-Ghamdi, S. 1998. Obstacles to successful implementation of strategic decisions: The British experience. European Business Review 98: 322-327. 
Al-Ghamdi, S. 2005. Communicating a Strategy to Employees: An Empirical Study on Saudi Manufacturing Company. King Fahd University of Petroleum and Minerals

Beer, M., R. A. Eisentat, and B. Spector. 1990. Why change programs don't produce change. Harvard Business Review (Nov-Dec): 158-166.

Beer, M., and R. A. Eisenstat. 2000. The silent killers of strategy implementation and learning. Sloan Management Review 41 (4): 29-40.

Boasson, V. W. 2001. Location, Strategy and Firm Performance: Evidence from the Pharmaceutical Industry. Bufallo: State University of New York. ABI/INFORM Global. Publication No. AAT 3021877.

Bolton, B. J. 2006. Corporate governance and firm performance. ProQuest Dissertations and Theses. Boulder: University of Colorado.

Bossidy, L., and R. Charan. 2002. Execution The Discipline of Getting Things Done. New York: Crown Business

Bourgeois, L. J., and D. R. Brodwin. 1984 Strategic implementation: Five approaches to an elusive phenomenon. Strategic Management Journal 5 (3): 241-264.

Bower, J. L., and C. G. Gilbert. 2007. How Managers' Everyday Decisions Create—or Destroy-Your Company's Strategy. Boston: Harvard Business School Publishing Corporation

Brauer, M., and S. L. Schmidt. 2006. Exploring strategy implementation consistency over time: The moderating effects of industry velocity and firm performance. Journal of Management dan Governance 10: 205-226.

Brown, J. E. 2000. A Study of the Relationship between CEO. CFO. and COO Short-Term Compensation and Firm Performance. California: California School of Professional Psychology. ABI/INFORM Global.Publication No. AAT 9964374.

Chong, H. 2003. A Causal Model of Linkages Among Strategy. Struktur. and Performance Using Directed Acyclic Graphs: A Manufacturing Subset of The Fortune 500 Industrials 1990 - 1998. Texas: A and M University

Curkovic, S., S. Vickery, and C. Droge. 2000. Quality-related action programs: Their impact on quality performance and firm performance. Decision Sciences 31 (4): 885.

Ghozali, I. 2008. Structural Equation Modelling: Metode Alternatif Dengan Partial Least Square. Semarang: Badan Penerbit Universitas Diponegoro, UNDIP.

Hacker, M. E., T. Kotnour, and L. A. Mallak. 2001. Formalizing deployment processes in the US government. International Journal of Public Sector Management 14 (3): 221-240.

Harrington, R. J., and K. W. Kendall. 2006. Strategy implementation success: The moderating effects of size and environmental complexity and the mediating effects of involvement. Journal of Hospitality Tourism Research 30: 207.

Jusoh, R., and J. A. Parnell. 2008. Competitive strategy and performance measurement in the Malaysian context: An exploratory study.Management Decision 46 (1): 5-31.

Kalali, N. S., M. R. Akhavan, A. A. Pourezzat, and D. K. Dastjerdi. 2011. Why does strategic plans implementation fail? A study in the health service sector of Iran. African Journal of Business Management 523: 9831-9837.

Kaplan, R. S., and D. P. Norton. 2001. The Strategy Focused Organization - How Balanced Scorecard Companies Thrive in The New Business Environment. Boston: Harvard Business School Press. 
Kaplan, R. S., and D. P. Norton. 2005. Creating the office of strategy management. Working Paper (unpublished). Balanced Scorecard Collaborative. www.hbs.edu.

Kaplan, R. S., and D. P. Norton. 2008. Execution Premium: Linking Strategy to Operations for Competitive Advantage. Boston: Harvard Business School Press.

Kazmi, A. 2008. A proposed framework for strategy implementation in the Indian context. Management Decision 46 (10): 1564-1581.

Lingle, J., and W. Schiemann. 1994. Is data scatter subverting your strategy. Management Review 83 (5): 53-6.

Low, J, and T. Siesfield. 1998. Measures that matter: Non-financial performance.Strategy and Leadership 26 (2): 24-38.

Miller, A., and G. Dess. 1997. Strategic Management (International ed.). New York: McGraw-Hill.

Mintzberg, H., B. Ahlstrand, and J. Lampel. 1998. Strategy Safari. New Jersey: Prentice-Hall.

Neilson, G. L., K. L. Martin, and E. Powers. 2008. The secrets to successful strategy execution. Harvard Business Review 86 (6): 60-70.

Noble, C. H. 1999. The eclectic roots of strategy implementation research. Journal of Business Research 45. 119-134.

Nohria, N., W. Joyce, and B. Roberson. 2003. What really works. Harvard Business Review 81 (7): 42-52.

Okumus, F. 2003. A framework to implement strategies in organizations. Management Decision 41 (9): 871 82.

Olson, E. M., and S. F. Slater. 2002. The balanced scorecard, competitive strategy, and performance. Business Horizon (May-June): 11-16.

Pella, D. A. 2010. Tujuh Langkah Transformasi Manajemen Kinerja Korporasi: Rahasia Peningkatan Kinerja Bisnis. Jakarta:Republika

Peljhan, D. 2006. The role of management control system in strategy implementation: The case of Slovenian company. Paper presented in Research Seminar at the University of Ljubljana.

Peters, T., and R. H. Waterman. 1980. In Search Of Excellence: Lessons from America's Best-Run Companies. UK:Bloomsbury

Peters, R. C. 2007. Corporate Social Responsibility and Strategic Performance. Realizing A Competitive Advantage Through corporate Social Reputation and A Stakeholder Network. Approach. Florida Atlantic University. Proquest Dissertation and Theses

Ramaseshan, B. 1998. Internal success factors for marketing strategy implementation. Conference Proceedings (9 ABI/INFORM Global): 68. American Marketing Association.

Rampersad, H. K. 2003. Total Performance Scorecard, Redefine Management to Achieve Performance with Integrity. Burlington: Butterworth-Heinemann

Roth, K., D. M. Schweiger, and A. J. Morrison. 1991. Global strategy implementation at the business unit level: Operational capabilities and administrative mechanism. Journal of International Business Studies 22 (3): 369.

Saunders, M., R. Mann, and R. Smith. 2007. Benchmarking strategy deployment practices. Benchmarking 145: 609-623.

Saunders, M., R. Mann, and R. Smith R. 2008. Implementing strategic initiatives: A framework of leading practices. International Journal of Operations dan Production Management 28 (11): 1095-1123. 
Schmelzer, C. D., and M. D. Olsen. 1994. A data based strategy implementation framework for companies in the restaurant industry. International Journal of Hospitality Management 13 (4): 347-359.

Schneier, C. E., D. G. Shaw, and R. W. Beatty. 1991. Performance measurement and management: A tool for strategy execution. Human Resource Management 30 (3) (1986-1998): 279.

Shah, A. M. 2005 The foundations of successful strategy implementation: Overcoming the obstacles. Global Business Review 6: 293.

Simons, R. 2000. Performance Measurement dan Control Systems for Implementing Strategy. New Jersey: Prentice Hall Inc

Skivington, E. J., L. R. Daft. 1991. A study of organizational framework and process modalities for the implementation of business level strategic decisions. Journal of Management Studies 28 (1): 45-68.

Sull, D. N. 2005. Why Good Companies Go Bad and How Great Managers Remake Them. Boston: Harvard Business School Press

Syrett, M. 2007. Successful strategy execution. How to keep your business goals on Ttarget. The Economist.

Tan, Y. T. 2004. Barriers to Strategy Implementation, Study of Air New Zealand. Auckland University of Technology

Tessema, M., and J. Soeters. 2006. Challenges and prospects of HRM in developing countries: Testing the HRM-performance link in Eritrean civil service. International Journal of Human Resource Management 171: 86-105.

Teng, M. 2002. Corporate Turnaround: Nursing A Sick Company Back to Health. Singapore: Prentice Hall

Yamin, S., and H. Kurniawan. 2011. Generasi Baru Mengolah Data Penelitian dengan Partial Least Square Path Modeling, Aplikasi dengan Software XLSTAT, SmartPLS dan Visual PLS. Jakarta: Salemba Infotek. 